\title{
Príncipes negros nas \\ festas de brancos: \\ Poder, revolta e identidades \\ escravas nas Minas setecentistas
}

Black Princes in White Parties:

Power, Rebellion and Slave Identities

in the $18^{\text {th }}$ century Minas Gerais

Renato da Silva Dias

Professor no Departamento de História da Universidade Estadual de Montes Claros (UNIMONTESMontes Claros/Brasil) e doutor em História pela Universidade Federal de Minas Gerais (FAFICH/UFMGBelo Horizonte/Brasil) e-mail: dias.reno@gmail.com

\section{Resumo}

Este artigo tem como objetivo principal apontar para a apropriação das festas religiosas pelos cativos nas Minas setecentistas a partir de um estudo de caso: a tentativa de sublevação escrava de 1719. Deseja-se também discutir a construção das identidades negras nesta capitania, destacando o confronto entre duas lógicas, a "étnica", trazida pelos africanos escravizados, e a "colonial", que incorpora identidades múltiplas. Na organização da sublevação estas duas lógicas estavam presentes, e 0 impasse criado no momento da escolha do líder da revolta resultou no seu desmantelamento. Longe de servir como mecanismo de controle social, a religião foi reinterpretada pelos cativos como forma de reconstruir suas identidades, para se protegerem e reafirmarem direitos. Do mesmo modo, as festas foram propícias para organizar sublevações.

\section{Abstract}

This article aims to show the appropriation of religious parties by slaves in the eighteenth-century Minas Gerais from a case study: the attempt of slave rebellion in 1719. We also want to discuss the construction of black identities in this captaincy, highlighting the battle between two logics, the "ethnic" brought by enslaved Africans, and the "colonial" which incorporates multiple identities. In the organization of this rebellion these two logics were present, and the impasse created when choosing the rebellion leader resulted in its dismantling. Far from serving as a mechanism of social control, religion was reinterpreted by the captives as a way to reconstruct their identities, to protect themselves and reaffirm their rights. Similarly, the parties were convenient to organize rebellions.

Palavras-chave

escravidão, poder, identidades

Keywords

slavery, power, identities 
1

A este respeito conferir: JANCSÓ, István; KANTOR, Íris (orgs.). Festa, cultura e sociabilidade na América Portuguesa. São Paulo: Hucitec/ Edusp/Fapesp: Imprensa Oficial, 2001.

NUNES, Márcia Clementino. História e significação simbólica da Festa do Rosário do Serro. Vária História, revista do departamento de História, Belo Horizonte, p.154, junho de 1988.

3

KARASCH, Mary. A vida dos escravos no Rio de Janeiro (1808-1850). São Paulo: Companhia das Letras, 2000. p.366-368.

4

Natalie Zemon Davis atesta que as inversões hierárquicas tanto podem servir como "válvula de escape", aliviando conflitos sociais latentes à sociedade ou, na contramão, agir como estopim para detonar um conflito. Culturas do povo: sociedade e cultura no início da França Moderna. Rio de Janeiro: Paz e Terra, 1990. p.112. Ao analisar as festas populares entre os séculos XVI e XVIII, Yves-Marie Bercé percebeu que estas poderiam refluir para a violência, por isso eram controladas pelos governantes. Fête et Révolte: des mentalités populaires du XVle. au XVIIIe. siécle. Paris: Hachette, 1994. p.56.

5

Arquivo Público Mineiro (APM), Secretaria de Governo (Sessão Colonial), códice 11, folha 170. Carta do governador, D. Pedro Miguel de Almeida Portugal, conde de Assumar, ao ouvidor geral da comarca do Rio das Velhas. Vila Rica, 21 de outubro de 1719. Doravante, usarei a sigla SC para me referir aos documentos da Sessão Colonial.

6

REIS, João José; SILVA, Eduardo. Negociação e conflito: a resistência negra no Brasil escravista. São Paulo: Companhia das Letras, 1989. p.123-130.

7

Destaca-se que para os escravos o conceito "parente" era ampliado, correspondia, dentre outros, à família putativa, mas também aos parentes espirituais, como padrinhos e madrinhas, os integrantes de uma mesma irmandade, os malungos, "companheiros de viagem" na travessia para a escravidão, os companheiros de trabalho. KARASCH, Mary. Op. Cit.

8

Era recorrente a publicação de bandos proibindo as vendas de secos e molhados nos morros onde havia negros, pois os mesmos desviavam recursos de seus senhores. Conferir: APM, Câmara Municipal de Mariana (CMM), Códice 04, fl.157-158. Bando de Dom Lourenço de Almeida, proibindo a venda de secos e molhados a homens livres e escravos no Morro de Mata Cavalo. Vila Rica, 14 de maio de 1722.

\section{Introdução}

$\mathrm{Na}$ atualidade, o estudo sobre as festas tomou grande fôlego e, observando o tema de perto, pode-se perceber uma grande variedade de enfoques. ${ }^{1}$ Eventos que ensejam vivências múltiplas, torna-se difícil avaliar a extensão e a variedade dos significados conferidos pela população e, particularmente, pelos escravos, às festas, mesmo as religiosas. Entre os cativos certamente haveria aqueles mais devotos, que se dedicavam mais ao culto divino - primeira parte das celebrações festivas, que antecediam aos folguedos públicos -, outros valorizavam mais o aspecto social, a participação nas procissões, onde representavam suas irmandades religiosas. Havia ainda aqueles que, movidos por intenções menos piedosas, aproveitavam para se divertir e até mesmo para troçar de seus senhores, como nas festas dos catopês, ${ }^{2}$ de São Gonçalo Garcia, ou na malhação do Judas: ${ }^{3}$ momentos de inversão ritualizada, que conferia ao grupo senso de identidade social e de reafirmação da recusa à submissão. ${ }^{4}$

As festas religiosas foram apreendidas por muitos estudiosos como forma de ordenamento social, uma vez que inseria os moradores nos cortejos, segundo sua condição na hierarquia social. Todavia, essa leitura centra-se unicamente nas "visões de mundo" europeias, e não se apercebe do "outro", nesse caso, das práticas e representações culturais construídas pelos escravos, africanos e descendentes. Acredita-se que as festas religiosas também eram momentos propícios para os cativos "desafogarem" suas tristezas e até mesmo para se revoltarem, sendo este um dos temores constantes nas Minas setecentistas, onde se receava a repetição do nefasto incidente dos "Palmares de Pernambuco", ou seja, de uma grande sublevação negra que pusesse termo ao mando régio nessas paragens. A documentação cotejada - constituída em sua maior parte de cartas do governador ao rei e às demais autoridades coloniais, que compõem o fundo secretaria de governo (antiga sessão colonial) - associa constantemente as festas religiosas, sobretudo a Semana Santa, às sublevações escravas. ${ }^{5}$

0 objetivo do presente artigo é analisar a apropriação das festas religiosas pelos negros, nas Minas setecentistas, a partir de um estudo de caso: a tentativa de sublevação escrava de 1719. Deseja-se também correlacionar a construção das identidades escravas nas Minas, a partir desse evento, destacando o confronto entre duas lógicas, a "étnica", trazida pelos africanos escravizados, e a "colonial", que incorpora identidades múltiplas. Não se tem a pretensão de esgotar o assunto, mas de trazer à luz questões que possibilitam dar maior visibilidade na análise do político e no entendimento da religião entre os cativos. Acredita-se que, longe de servirem como instrumento pedagógico, de controle social, os escravos reinterpretavam a religião e as festas religiosas, forma de reconstruir suas identidades, de se protegerem dos senhores e reafirmarem direitos: época propícia para organizar sublevações.

\section{Por dentro da festa}

Levando uma vida durissima, com escassas oportunidades para a descontração, a festa religiosa era oportunidade impar para o escravo "brincar, folgar, e cantar". ${ }^{6}$ Hora de rever amigos, familiares, "malungos" e "parentes", 7 que chegavam de várias regiões. Ali comiam e bebiam, às vezes com o dinheiro extraviado de seus senhores, ${ }^{8}$ dançavam e se esqueciam de sua condição e que, nos próximos dias, voltariam ao trabalho. Enfim, tais celebrações propiciavam ocasião especial aos 
9

BOWSER, Frederick. El Esclavo africano en el Perú colonial (1524-1650). México: 1970. p.290-291; PEREIRA, Nuno Marques. Compêndio narrativo do peregrino da América. Rio de Janeiro: Academia Brasileira, 1939. p.123-126.

10

SC, cód.46, fl.38. Carta do rei ao governador. 05 de novembro de 1735. Sobre o assunto, ver o instigante trabalho de GUIMARÃES, Carlos Magno. Cada venda é um quilombo: escravismo e espaço de rebeldia nas Minas Gerais (século XVIII). Anais da $5^{a}$ Jornada Setecentista. Curitiba, 26-28 nov. 2003.

11

Emília Viotti da Costa afirmou que os escravos reinterpretavam a religião, não sendo mais então a religião do senhor dominador, mas a religião dos homens de cor. Da Senzala à colônia. São Paulo: Difusão Europeia do Livro, [s/d]., p.234-239. Essa análise é aprofundada em: DIAS, Renato da Silva. Para glória de Deus, e do Rei? Política, religião e escravidão nas Minas do Ouro (1693-1745). 2004. 451f. Tese (Doutorado em História). Faculdade de Filosofia e Ciências Humanas, Universidade Federal de Minas Gerais, Belo Horizonte, 2004

12

REIS, João José. Magia Jeje na Bahia: a invasão do Calundu no Pasto de Cachoeira, 1785. Revisto Brasileira de História, São Paulo, p.57-81, 1988.

13

Segundo Michel Maffesoli, os individuos ou comunidades submetidos por outros grupos que não tinham condições de se libertarem devido à disparidade das forças faziam "como se", ou seja, iam levando a vida, esperando o momento certo para se libertarem. A transfiguração do político: a tribalização do mundo. Porto Alegre: Sulina, 1997. Conferir também: SCOTT, James. Weapons of the weak: everyday forms of peasant resistance. New Haven/ London: Yale University Press, 1985.

14

GENOVESE, Eugene. Roll, Jordan, Roll: the world the slave made. New York: Vintage Books, 1976; KARASCH, Mary. Op. Cit.; SOUZA, Marina de Melo e. Reis negros no Brasil escravista: história da Festa de Coroação de Rei Congo. Belo Horizonte: Editora UFMG, 2002; SOARES, Mariza de Carvalho. Devotos da cor: identidade étnica, religiosidade e escravidão no Rio de Janeiro, século XVIII. Rio de Janeiro: Civilização Brasileira 2000.

15

Sobre as diversões nas festas coloniais conferir livro: JANCSÓ, István; KANTOR, Íris (orgs.). 0p. Cit., 2001.

16

Sobre a justificação teológica da escravidão africana, conferir: DIAS, Renato da Silva. Ethiopes de Guiné: o escravismo colonial sob as lentes do padre Antônio Vieira. Vínculo: revista de Letras da Unimontes, vol.7, n.01, p.173-196, dezembro de 2006; VAINFAS, Ronaldo. Ideologia e Escravidão: Os letrados e a sociedade escravista no Brasil colonial. Petrópolis: Vozes, 1986 mancípios, permitindo-Ihes dar vazão a sentimentos contidos pois, mesmo para aqueles que preferiam diversões profanas, como os batuques e calundus, ${ }^{9}$ na sua ausência, os escravos davam outros sentidos às comemorações piedosas, ressignificando-as, tornando-as festas das gentes de cor.

Nesses momentos em que a vigilância mostrava-se menos eficiente por causa do volume de circundantes, os escravos podiam viver mais livremente, esquecer as tristezas, confraternizar-se com os amigos, encontrar o sexo oposto. No caso dos homens, em desvantagem nesse mercado amoroso, poderiam até dar uma escapadela e ir buscá-lo, mesmo que de forma efêmera, nas "casas de alcouce", nas tavernas de má fama. ${ }^{10}$ Apesar do seu significado simbólico, que se remete ao imaginário cristão, nas festas religiosas e celebrações régias, as gens de couleur aproveitavam para viver livres da presença de seus proprietários, para se divertir e ainda para resolver desavenças. Além do aspecto lúdico, a ocasião favorecia algo muito importante para os cativos: eles se colocavam a par dos acontecimentos.

Os escravos reinterpretavam a religião dos senhores a partir de seus olhares. ${ }^{11}$ Assim, eles asseguravam, além do conforto espiritual, benefícios para si e para seu grupo familiar ou de pertencimento. Observe-se que não há contradição alguma no fato dos escravos cultivarem intensa devoção aos santos, anjos e outros aspectos da piedade católica, pois isso não os impedia de vivenciarem as suas próprias manifestações religiosas, à noite ou às escondidas, ${ }^{12}$ mas sempre na medida do possível, para não levantar suspeitas, pois tais práticas eram proibidas. Apropriando-se do catolicismo e fazendo como $\mathrm{se}^{13}$, os mancípios buscavam viver da melhor maneira. Assim, esses eventos, próprios da ritualidade católica, tornaram-se comemorações que continham grande carga simbólica para os africanos e descendentes, uma vez que também faziam rememorar suas festas coletivas. ${ }^{14}$

Se os africanos e descendentes escravizados participavam do catolicismo de forma diferenciada, nas distintas ocasiões do ano litúrgico e nos rituais religiosos, - vivendo com maior ênfase as "datas fortes", como as festas, e rituais como o batismo, o casamento e a morte, ritos de passagem importantes em suas "visões de mundo" - as datas festivas também eram marcadas por rupturas. Nesses eventos, havia momentos mais solenes, como a missa e a procissão, e aqueles de teor mais profano, como os jogos diversos, as cavalhadas, as argolinhas e os curros $_{1}{ }^{15}$ o que permitia participação diferenciada dos cativos.

Os mancípios passaram a reler astutamente o catolicismo. Conhecendo o credo de seus senhores, adquiriram argumentos, jogando com suas armas, descobrindo os seus direitos e como obter vantagens. Participavam das festas e demais atos litúrgicos, mas não se submetiam ou aceitavam a condição de "mercadoria" imposta pelo sistema, eles reinterpretavam a religião a seu favor, acatando aquilo que poderia favorecê-los e rejeitando o argumento de que a escravidão era "justa por natureza". ${ }^{16}$

\section{As revoltas escravas nas festas de brancos}

Em diversas regiões, onde o escravismo foi implantado como sistema, os cativos aproveitavam-se das épocas festivas - quando os senhores estavam envolvidos nas celebrações, e a vigilância era menos eficiente - para fugir 
Eugene Genovese afirma que os escravos escapavam ou organizavam revoluções preferencialmente na época natalina, quando seus senhores estavam preocupados com os preparativos da mesma. Op. Cit., p.580-582. Segundo Frederick Bowser, no Peru colonial os escravos preferiam se evadir na Semana Santa. Op. Cit., p.237.

18

SC, cod.11, fl.118-118v. Carta do governador, D. Pedro Miguel de Almeida Portugal, conde de Assumar, para o ouvidor do Rio das Mortes. Vila do Carmo, 24 de março de 1719.

19

Trata-se, neste caso, da Capitania de São Paulo e Minas do Ouro, pois somente em 1720 a Capitania das Minas do Ouro se tornou independente da de São Paulo.

SC, cod.11, fl.130-133v. Carta do governador a Bartolomeu de Souza. Vila do Carmo, 01 de junho de 1719. [grifos meus]. e, no extremo, para organizarem rebeliões. ${ }^{17}$ Esse foi o caso das Minas setecentistas, quando, por diversas ocasiões, os mancípios buscaram organizar-se coletivamente para se sublevarem nas épocas festivas, a exemplo da Semana Santa, uma clara demonstração da astúcia escrava. Mas vamos aos fatos.

Em carta datada de 21 de março de 1719, o ouvidor da comarca do Rio das Mortes informou a D. Pedro Miguel de Almeida Portugal a suspeita de um levantamento dos escravos naquela região. Em resposta à missiva, este governador ordenou a averiguação da notícia, mas asseverou que o perigo maior não estaria tanto nas consequências diretas de um ataque, uma vez que os negros eram desorganizados, mas sim no "terror pânico dos brancos", que imprimia "maior atrevimento" aos mancípios. Essa foi a primeira advertência da preterida sublevação escrava, mas o conde de Assumar receberia (e escreveria) muitas outras. ${ }^{18}$ Nota-se que a mais alta autoridade da capitania ${ }^{19}$ já havia se dado conta do medo que rondava as vilas e arraiais, e fustigava o imaginário coletivo, aumentando os "atrevimentos" da escravaria.

Avisos da sublevação negra, marcada para ocorrer na quinta-feira Santa, ou "das endoenças", chegavam de vários confins das Minas. Além das notícias provenientes da comarca do Rio das Mortes que, a princípio, não foi dada importância, "por ser de causa já intentada muitas vezes e sempre desvanecida", outras cartas vieram do distrito do Furquim, de São Bartolomeu e de Vila Rica, merecendo agora maior cautela, pois os mesmos se organizavam:

convocando-se uns e outros e comunicando-se de todas as partes destas Minas ainda das mais distantes por via de seus emissários trataram uma sublevação geral e a levarão tanto a diante que tinham disposto levantarem-se em todas aquelas partes no dia de quinta feira santa destinado para essa função, porque supondo aos homens brancos divertidos com a assistência das igrejas se thes fique ou podiam ter a comodidade de arrombar as casas em que estavam as armas, e aproveitando-se delas e do mais que tinham prevenido investir com os homens brancos e matando-os a todos ficarem senhoreando o pais para este efeito tinham nomeado em todos os distritos Reis, Príncipes, e oficiais militares e outros empregos, tinham feito prevenção de algumas armas, pólvora e balas, bandeiras e insígnias $[\mathrm{sic}] .^{20}$

A extensa citação se faz jus, pois a paráfrase certamente tiraria o brilho do documento. Deste modo, "como eram idênticas as circunstâncias", Assumar tomou algumas medidas preventivas: ordenou a prisão de todos os "negros suspeitosos", mandou vigiar as estradas e locais de maior concentração de escravos e dirigiu-se para Vila Rica, região de maior perigo, "pois naquele morro mineram [de] três para quatro mil negros", onde determinou a busca das armas. Contudo, somente umas poucas foram encontradas, talvez porque os cativos tivessem-nas escondido "nas casas subterrâneas que fabricam com o mesmo exercicio de minerar [sic]". Eram muitas as dificuldades para dominar os pretos evadidos, e mais ainda para debelar uma sublevação, pois, além dos altos custos, não é possivel subestimar os fatores geográficos, logísticos e humanos.

Era profuso o número de mancípios que fugiam, e altas as despesas necessárias para combatê-los, apesar de indispensáveis, principalmente por tratar-se de uma região tão importante para o reino, localizada nos sertões interiores da América portuguesa, habitada por uma população tida como 
Segundo Mariza Soares, o termo "nação" não se refere a nenhuma identidade étnica ou cultural africana especifica, ele foi criado pelos colonizadores para definir, dentre outros, as regiões de origem dos escravos, portos ou mercados abastecedores. Sobre as "nações e grupos de procedências" africanas, conferir SOARES, Mariza de Carvalho. Op. Cit., p.93-127.

22

Trata-se, neste caso, do Code Noir.

23

SC, cod.11, fl.130-133v. Carta de D. Pedro de Almeida a Bartolomeu de Souza. Vila do Carmo, 01 de junho de 1719. Dentre tais medidas, Assumar sugeriu a D. João $\checkmark$ que se permitisse cortar o "artelho do pé" (tendão de Aquiles) dos escravos, ou ainda amputar uma das suas pernas como "castigo exemplar". Tais medidas, consideradas rudes por muitas autoridades, marcaram esse governador na historiografia como cruel. Contudo, ao se fazer uma análise comparativa das formas de punição dos escravos nas Américas observa-se que muitas das medidas usadas como forma de punição dos escravos eram semelhantes, a exemplo do açoitamento no pelourinho, do corte das orelhas dos fujões, da marcação com ferro quente, do corte das cabeças dos líderes das revoltas, além de outras formas de sevícias. Sobre este aspecto conferir: FICK Carolyn E. The Making of Haiti: the Saint Domingue Revolution from Below. Knoxville: The University of Tennesee Press, 1990. p.35 e p.53; BOWSER, Frederick. Op. Cit., p253; GENOVESE, Eugene. Op. Cit.; PRICE, Richard (ed.) Maroons Societies: rebel slave communities in the Americas. Baltimore and London: Johns Hopkins University Press, 1979. p.38, e p.75.

24

SC, cod.11, fl.130-133v. Carta do governador a Bartolomeu de Souza. Vila do Carmo, 01 de junho de 1719.

25

Para uma visão comparativa conferir: GENOVESE, Eugene. Op. Cit.,; PRICE, Richard (ed). Op. Cit.; BOWSER, Frederick El control del africano: crimen y sedición. In: Op. Cit., p. 198-241.

26

Sobre o comércio com os escravos conferir: CMM, cod.04, fls.157-158. Bando de Dom Lourenço de Almeida, proibindo a venda de secos e molhados a homens livres e escravos no Morro de Mata Cavalo. Vila Rica, 14 de maio de 722 e SC, cod.37, fls.61$61 \mathrm{v}$. Bando determinando o que é proibido vender aos negros e estabelecendo o limite de distância entre as negras com tabuleiro e os negros que trabalham. Vila Rica, 21 de setembro de 1734

27

0 Triunfo Eucarístico (1733) tratou-se da comemoração realizada em decorrência da devolução do santíssimo sacramento, que estava depositado na Igreja do Rosário, para a matriz do Pilar, em Vila Rica. O Áureo Trono Episcopal(1749) narrou a celebração pela chegada do primeiro bispo no recém-criado Bispado de Mariana, D. Frei Manoel da Cruz, em 1747. Graças a Affonso Ávila, incansável pesquisador do Barroco mineiro, a historiografia pôde cotejar tais relatos, que tipificam muito bem as festas coloniais e são clara expressão das "visões de mundo" setecentista. Os textos fac-similados encontram-se em Resíduos Seiscentistas em Minas: textos do século do ouro e as projeções do mundo barroco. Belo Horizonte: Centro de Estudos Mineiros, 1967. p.11-51. insubmissa e por grande número de escravos rebeldes, como os da costa da Mina, "que são sumamente intrépidos". As autoridades mineiras temiam os escravos desta "nação", ${ }^{21}$ tidos como destemidos, por isso muitas vezes tornava-se necessário o envio de tropas para submetê-los "por bosques e desfiladeiros impenetráveis". Diante de situação de iminente fracasso, D. Pedro de Almeida aconselhou ao rei, D. João V, baseando-se nas ações que Luís XIV supostamente teria tomado na Martinica e na Louisiana, a exemplo da criação do "códice negro", ${ }^{22}$ que seria necessário a adoção de medidas mais severas, sob o risco de se perderem as Minas. ${ }^{23}$

Outra resolução tomada de imediato foi a ordem para perseguição e prisão de "todos os negros suspeitosos e indiciados", tarefa que ficou a cargo do tenente general Francisco Tavares, que capturou vários escravos nos dias seguintes, em Vila Rica e por outras partes. Posteriormente, esse tenente apanhou também "os chamados Reis e Príncipes e outros mais nomeados cabos da sublevação", que foram remetidos à Vila do Carmo, onde ficaram detidos para que se pacificassem as desordens. Além disso, foi publicado um bando proibindo o uso de armas na Semana Santa. Com 0 intuito de prevenir quaisquer tentativas de revolta naquele ano, foram introduzidas as "campanhas de guardas", com grande número de soldados nas Igrejas, além da recomendação dada aos senhores para removerem as armas das regiões de risco, ou ainda, caso isso não fosse possivel, "ordenei que se lhes tirassem os fechos [das armas] e se escondessem em parte onde os negros os não pudessem descobrir [sic]".24

As medidas tomadas para se evitar e/ou desarticular a rebelião escrava não foram de todo novas. Na verdade, eram bastante comuns nos sistemas escravistas americanos, como as rondas noturnas, usadas para limitar a circulação e ajuntamentos de negros nesses horários; a repressão aos crimes e a apreensão dos suspeitos; o desarmamento dos cativos; as punições públicas dos escravos, no pelourinho, como medida pedagógica para o controle da violência e, por fim, a prisão e multa dos senhores que permitiam aos escravos o porte de armas. ${ }^{25}$

Nas Minas, muitos escravos eram treinados no uso de armas de fogo, para segurança pessoal dos senhores, que os usavam como escoltas, ou pelos agentes da administração, como força auxiliar no combate aos pretos fugidos. Certo é que esse conhecimento era repassado aos quilombolas, que se tornavam um perigo em potencial, pois, além de conhecerem como poucos a região, eles teciam relações com escravos amigos, que os assistiam, com outros outsiders sociais e comerciantes inescrupulosos. ${ }^{26}$

Ao mesmo tempo em que atraíam a população, que ansiava por assistir às procissões, aos desfiles dos carros triunfantes, fogos de artifício e jogos, como é relatado no Triunfo Eucarístico e no Áureo Trono Episcopal, ${ }^{27}$ as festas religiosas tornavam-se ocasiões propícias para acertos de contas e para fomentar revoltas, pois, diante do calor que o álcool açodava, a multidão torvava-se mais audaz e turbulenta, perdendo mais facilmente o controle. Assim, fatos que de outro modo seriam tolerados, poderiam, nessas circunstâncias, desencadear mortes ou sublevações escravas.

Foram vários, e de distantes regiões, os "cabeças" da malograda tentativa de sublevação. Entre os suspeitos, estavam o sargento-mor negro [Helano] da Motta [sic], provavelmente um "sargento do mato", perseguidor de quilombolas, dois pretos do marechal de campo Ambrósio Caldeira e alguns do ouvidor Valério da Costa, que se opôs terminantemente à apreensão de seus mancípios e de Ambrósio Caldeira, "seu 
SC, cod.11, fls.122-122v. Carta de D. Pedro de Almeida ao ouvidor da comarca do Rio das Mortes. Vila do Carmo, 05 de abril de 1719.

29

SC, cod.11, fls.130-133v. Carta de D. Pedro de Almeida para Bartolomeu de Souza Alexandre. Vila do Carmo, 01 de junho de 1719.

30

SC, cod.11, fls.119-119v. Carta de D. Pedro de Almeida ao ouvidor do Rio das Mortes. Vila do Carmo, 13 de abril de 1719

31

SC, cod.04, fls.218-219v. Carta de D. Pedro de Almeida ao rei, D. João V. Vila do Carmo, 20 de abril de 1719 .

32

SC, cod.11, fl.119v/120. Carta de D. Pedro de Almeida ao tenente general João Francisco Tavares. Vila do Carmo, 03 de abril de 1719.

33

SC, cod.11, fls.124-124v. Carta de Assumar ao marechal de campo Paschoal da Silva Guimarães, s/l, s/d. [grifos meus].

34

Ibidem.

35

SLENES, Robert W. Na senzala, uma flor:

esperanças e recordações na formação da família escrava, Brasil Sudeste, século XIX. Rio de Janeiro: Nova Fronteira, 1999

36

RUSSELL-WOOD, A J R. The black man in slavery and freedom in Colonial Brazil. New York, s/ed., 1982. parente", gerando um conflito de poder que também incluía o tenentegeneral Francisco Tavares, acusado pelo ouvidor de ser "trapaceiro, caviloso e subordinador de testemunhas", fato que atravancou ainda mais a resolução do caso. ${ }^{28}$

Apesar de ser repreendido várias vezes pelo conde de Assumar, que deu ordens expressas para se fazer uma devassa, o ouvidor Valério da Costa preferiu ignorá-las, afirmando que tudo não passava de uma "máquina armada" por Francisco Tavares contra os seus negros e os de Ambrósio Caldeira. Esse fato mereceu severas reprimendas do governador, que informou àquele que os avisos sobre a sublevação chegaram de diversas vilas e que, portanto, não era caso preparado pelo tenente. Além disso, D. Pedro ordenou que o mesmo desarmasse os seus escravos, posto que esta prática já fora proibida em diversos bandos, e que se entendesse com o tenente-general. ${ }^{29}$

Terminadas as devassas, provou-se o envolvimento dos escravos do marechal de campo, do ouvidor e de dez pretos do coronel Salvador, que assistia na região do Furquim, além de outros, castigados por apresentarem "indícios mais leves". ${ }^{30}$ Nota-se que, até esse momento, os líderes da pretendida sublevação pertenciam às figuras de destaque no meio colonial, como agentes da administração e militares, o que não era surpresa para $D$. Pedro de Almeida, já que, segundo ele mesmo, os negros se apoiavam na "néscia confiança de seus senhores", que Ihes entregavam "todo o gênero de armas", e ainda "Ihes encobriam as suas insolências e os seus delitos". Conforme relatou o governador, até mesmo o ouvidor Valério da Costa tinha um "brio mal entendido" com os seus escravos e, por isso, não permitia que fossem presos. A irritação de Assumar pelo descumprimento e desacato de suas ordens, por seus subordinados, levou-o a dar ordens expressas ao tenente-general João Francisco Tavares, que deveria entregar uma carta a Ambrósio Caldeira para que este apresentasse seus escravos, presos, ao tenente. Mas se acaso o marechal de campo não cumprisse tais ordens, 0 tenente deveria prendê-lo e levá-lo à Vila do Carmo. ${ }^{32}$ Nesse meio tempo, chegou de Itabira a seguinte notícia:

havia naquele distrito um negro forro de nação Mina, chamado Manoel casado com uma negra forra por nome Mariana em cuja casa se ajuntam os mais da mesma nação causando com os seus folguedos e insolências grande perturbação aos moradores e que se tinha por certo que o dito negro estava eleito entre os mais por cabeça para a sublevação dos negros daquele distrito [sic]. ${ }^{33}$

Além do casal citado acima, foi ordenada a prisão da negra mina Isabel, que também participava dos "folguedos" feitos por ocasião da eleição dos reis dessa nação, o que deveria ocorrer em segredo, pois "dizem que eles andam já com algum receio depois das prisões dos outros negros". ${ }^{34} 0$ que se destaca, nesse caso, é a suspeita da organização da sublevação em uma festa particular, onde se reuniram africanos de mesma origem: a Costa da Mina. Estes indivíduos apresentavam similaridades culturais, e, pelo que se percebe, construíram uma identidade comum, talvez se comunicando pela "língua geral da Costa". ${ }^{35}$ Além disso, outro ponto de destaque é que, dentre os "cabeças" da revolta, havia forros, o que demonstra que os libertos não eram absolutamente avessos aos desejos de liberdade dos escravos. Pelo contrário, muitos deles eram solidários e não se isentavam de participar ou de liderar tais rebeliões. ${ }^{36}$ 
DIAS, Renato da Silva. Na África eu nasci, no Brasil eu me criei: a evangelização dos escravos nas Minas do Ouro. In: PAIVA, Eduardo França; IVO, Isnara Pereira (orgs). Escravidão, mestiçagem e histórias comparadas. São Paulo: Annablume Belo Horizonte: PPGH-UFMG; Vitória da Conquista: Edunesb, 2008. p.293-310.

38

SOUZA, Marina de Melo e. Op. Cit., p.37, p.152 e p.167.

39 MAFFESOLI, Michel. Op. Cit.SCOT, James. Op. Cit.

40

SC, cod.11, fl.124-124v. Carta de Assumar ao marechal de campo Paschoal da Silva Guimarães, $s / l, s / d, 1719$.
Nesse caso, esses eram seus organizadores preferenciais, juntamente com os cativos das pessoas mais ilustres. Nota-se ainda que os líderes eram casados, termo que, além de indicar que eles contraíram seus esponsais in faccie eclesiae, permite questionar se a religião e a formação da família escrava eram mesmo elementos "estruturantes" do controle social. ${ }^{37}$ Destaca-se também que existe um grande fosso entre as representações políticas criadas pelos poderosos e as práticas cotidianas, que sempre serão mais dinâmicas e surpreendentes.

Mas será que essa festa comemorada pelos negros da "nação" Mina não era uma maneira de recriação identitária de um grupo com características culturais comuns? E mais, forma de reafirmar os laços de pertencimento social e de consolidar o elã comunitário no Novo Mundo? Em caso afirmativo, esse ritual de escolha de novos líderes remeteria às práticas culturais africanas? Torna-se, desta forma, necessário investigar as formas de representação do poder pelos africanos e analisar os processos desencadeados pelo "contato" entre as culturas da África e Europa para assegurar o melhor entendimento desse episódio. Em muitas regiões da África, as comunidades se organizavam em grandes reinos, como 0 do Daomé, na região de Acra; Loango, Tio, Matamba e o reino do Congo, na África "banto", comunidades estas que se apresentavam altamente organizadas e hierarquizadas, à semelhança das monarquias europeias da época Moderna. Assim, os títulos, rituais e símbolos de poder também eram utilizados pelos africanos para distinguir elementos pertencentes às elites. Destarte, quando os portugueses entraram em contato com o reino do Congo e batizaram as principais autoridades, estas adotaram os símbolos e a religião da corte portuguesa, vistos como fonte de poder, mas interpretando-os a partir de seu universo cultural. No Novo Mundo, os africanos escravizados desejavam manter suas identidades anteriores ao tráfico, mas, diante das dificuldades impostas pelo novo sistema social, foi necessário adaptar-se, apropriando e ressignificando as instituições e rituais que melhor respondiam aos seus anseios, nessas novas condições. Dessa forma, os ritos e cerimônias de poder passaram a existir sob a forma de eleição de reis, governadores, capitães e outros títulos da nobiliarquia europeia, mas que rememoravam uma identidade anterior ao tráfico. ${ }^{38}$ Como se vê, a eleição de um chefe ou "rei" africano é um indício importante de como percebiam seu mundo, recriando e recordando suas identidades e práticas ancestrais.

Denunciada a conspiração, é hora de fazer como se, ${ }^{39}$ dissimular obediência, voltar à normalidade e seguir as regras sociais para não despertar suspeitas. Porém, nesse caso, tais cativos, como os pertencentes ao ouvidor do Rio das Mortes, acusados de serem os "cabeças" da sublevação, tinham fama pública, pois estavam acostumados a desacatar os moradores e a dar mostras de valentia e insubordinação. A algazarra era costumeira, pois, no ano anterior, o próprio governador já ordenara ao juiz ordinário para "tirar uma exata informação do procedimento do dito negro", que tinha despertado a atenção e o descontentamento dos vizinhos, que haviam feito queixas "de seu mau viver". ${ }^{40}$

A informação de que a sublevação foi malograda pela "diferença de que os negros de Angola queriam que fosse rei de todos um dos do seu reyno e os Minas também que fosse da sua mesma pátria [sic]" só foi obtida em missiva posterior, de 1725 , quando o rei $D$. João $V$ pediu informações para saber como evitar a revolta dos negros. A carta que originou 
41

SC, cod.29, fl.03. Ordem Régia. Lisboa, 10 de junho de 1725 [grifos meus]. A partir de 17160 fornecimento para o Novo Mundo dos escravos "mina" diminuiu como resultado da crise no reino do Daomé, que parou de exportá-los, e da transferência dos interesses de Portugal para a região de Angola. Este foi o quarto maior grupo no fornecimento de escravos para o interior das Gerais, durante o periodo entre 1720 e 1888, representando $10,7 \%$ do total. BERGAD, Laird W. Slavery and the Demographic and Economic History of Minas Gerais, Brazil, 1720-1888. New York: Cambridge University Press, 1999. p.151.

42

Segundo Carolyn Fick, a Revolução do Haiti somente obteve sucesso em razão da construção de uma ideologia religiosa, o vodu, que permitiu a união dos escravos de diferentes grupos étnicoculturais em torno de um propósito comum: a conquista da liberdade. REIS e SILVA fazem observações semelhantes em relação à revolta dos Malês, na Bahia oitocentista, contudo, deixam algumas ressalvas: "A religião foi talvez a força ideológico-cultural mais poderosa de moderação das diferenças étnicas e sociais no interior da comunidade africana, embora tenha falhado em unir africanos e crioulos. Pelo fato de ter sido um meio de solidariedade interétnica, o islã ajudou a promover a unidade entre muitos escravos e libertos africanos. 0 islã representou um forte fator de mobilização e, obviamente, organizou os rebeldes de uma maneira sofisticada". FICK, Carolyn E. Op. Cit., 1990. REIS João José; SILVA, Eduardo. Op. Cit., p.110.

43

Embora a instituição da escravidão fosse uma dimensão inegável de conflitos sociais, que muito preocupavam os senhores e autoridades coloniais, fica claro também que os escravos se organizavam, e se dividiam, segundo seus grupos étnicos de origem, mas também em relação às diferenças criadas na colônia, entre "pretos" e "crioulos", negros e mestiços, escravos e libertos e, igualmente, em relação às atividades que exerciam, ou irmandades de que faziam parte. Dessa forma, o entendimento dos escravos enquanto classe social supõe a existência de uma solidariedade que suplantasse todas essas diferenças, ou, em termos marxistas, uma forte consciência de classe que os unia, em oposição aos brancos (dominadores), o que raramente ocorreu.

44

0 termo "ladino" se aplica tanto aos escravos nascidos na colônia, os "crioulos", conhecedores dessa cultura, mas também aos africanos, ou "pretos", quando já tinham experiência suficiente no trato cultural e sabiam também o português e as práticas sociais. SOARES, Mariza de Carvalho. Op. Cit., p.93-127.

45

GENOVESE, Eugene. Op. Cit., 1976.

46

SC, cod.04, fl.740-748. Carta de Assumar ao Rei. Informa sobre os meios utilizados pelas negras para obterem sua alforria e outros assuntos. s/ local, 28 de Novembro de 1719 [grifos meus]. essa ordem informava o perigo dos escravos tomarem o governo daquela região, destacando que reavê-la seria uma operação trabalhosa e arriscada, "sendo necessário todas as forças do Brasil [sic]". Para diminuir os riscos, o rei inquiriu D. Lourenço de Almeida, governador da capitania das Minas do Ouro, se seria conveniente que fossem àquela região somente os escravos de Angola, uma vez que "tem se visto que estes são mais confidentes e mais sujeitos e obedientes do que os Minas a quem o seu furor e valentia pode animar e entrarem nalguma deliberação de se oporem contra os brancos $[$ sic]".41

Nesse documento fica evidente que os mancípios estavam tentando reconstruir suas identidades a partir das referências culturais anteriores ao tráfico, ou seja, das características comuns que os uniam nos grupos "minas" e "angolas". Nota-se também que o elemento étnico se sobrepôs, neste caso, aos interesses e reivindicações comuns dos cativos no sistema escravista. Em outras palavras, a "lógica da tribo" foi maior que a solidariedade multicultural construída nas senzalas a partir de uma condição comum. Os escravos não conseguiam, na maioria das vezes, construir uma identidade pluri ou multicultural, ou uma ideologia própria que os unisse em contraposição aos brancos. ${ }^{42}$ Esse dado demonstra que não se pode pensar, como alguns desejam, os cativos como uma "classe social", uma vez que existiam diversas formas de construção identitária que favorecia a dissensão entre os negros. ${ }^{43}$

Fato que se destacou na sublevação malograda de 1719, e que confirmou a brilhante análise de Eugene Genovese para o sul dos Estados Unidos, é que os líderes dessas revoltas não eram, como se poderia esperar, africanos recém-chegados do tráfico atlântico, conhecidos como "boçais", ou cativos que trabalhavam nos campos. Para que as sublevações tivessem maiores chances de sucesso era imperativo conhecer melhor o mundo colonial, tecer relações com outros mancípios e com pessoas que pudessem ajudá-los, além de obter informações logísticas e ter carisma pessoal, necessário para manter a união do grupo e contornar as dissensões internas. Todas essas condições qualificavam melhor aqueles que nasciam no âmbito colonial, ou que foram traficados ainda jovens e se tornaram "ladinos". 44 No caso das Minas setecentistas, dentre os líderes identificados, parece que todos residiam nas vilas, eram escravos de confiança de seus senhores e conheciam as "manhas" da colônia, sendo alguns deles libertos. ${ }^{45}$ É importante lembrar que as uniões entre os negros já eram temidas na época, o que levou o governador, D. Pedro de Almeida, a proibir que estes fossem padrinhos de batismo e de casamento de outros indivíduos de igual condição, recomendando aos vigários que somente os brancos pudessem sê-lo, pois:

sendo os Padrinhos para doutrinarem, e instruírem na Santa Fé os afilhados, é bem notório que vindo os negros para esta conquista adultos, e ainda Bárbaros não poderão doutriná-los, e ensiná-los com a ciência e zelo com que o farão os homens brancos que se criaram com o leite da igreja o que facilmente não se encontra nos negros pela sua feroz natureza $[$ sic]".46

Esse excerto revela bem a "visão de mundo" daquela época e lugar, e os preconceitos em relação aos escravos. Apesar dessas recomendações, o desejo de Assumar de limitar como padrinhos dos escravos somente os brancos - o que significava para esse governador uma forma de controle 
CONSTITUIÇÕES PRIMEIRAS DO ARCEBISPADO DA BAHIA. Feitas e ordenadas pelo llustríssimo e Reverendíssimo Senhor D. Sebastião Monteiro da Vide. São Paulo: Tipografia de Antônio Louzada Antunes, 1853. Liv.I, Tit.XVIII, par. 64.

48

DIAS, Renato da Silva. Op. Cit. político - não tinha plena sustentação doutrinal e, portanto, não foi posto em prática pelos párocos mineiros. Nesse ponto, as Constituições deixam claro que, sendo o escravo ainda criança, aos pais cabe a escolha dos padrinhos; quando adultos, os próprios escravos deveriam eleger aqueles de sua preferência. ${ }^{47}$ Havia, no entanto, alguns impedimentos, como no caso dos infiéis, hereges, excomungados, interditos e "os que ignoram os principios de nossa Santa Fé", e esse é o ponto da questão. Assumar enquadrou os "boçais" e os "ladinos" nesta última categoria, pois somente os brancos, a seu ver, tinham "ciência e zêlo", uma vez que haviam se criado com "o leite da igreja", diferentemente dos negros, dotados de "feroz natureza".

Assumar acreditava que, na liderança da sublevação, estavam líderes africanos, tais como reis, príncipes ou membros de alguma família reinante, escravizados e transportados para a América portuguesa, e que, certamente, possuiam o carisma necessário para ter a confiança dos escravos de sua "nação". Entretanto, esses chefes também eram criados no âmbito colonial. Eram os ladinos e crioulos os cativos mais adaptados, porém nada submissos, pois sabiam melhor como explorar as ambiguidades daquele meio social. Dessa forma, percebe-se que analisar a Igreja como simples mecanismo de aculturação e dominação dos escravos mostra-se insuficiente para dar conta da realidade social, refletindo, sobretudo, teorias construídas a posteriori e, portanto, anacrônicas. ${ }^{48}$

\section{Reis na festa e na revolta}

Outra festa religiosa muito valorizada era a coroação dos reis e rainhas do Congo, acontecimento este que se desenrolava no interior das irmandades religiosas. Fato entendido por muitos senhores e autoridades como forma de dominar os escravos, e arquétipo do sucesso da obra evangelizadora do catolicismo triunfante, a eleição de reis negros é um bom exemplo da dupla interpretação da religião e, consequentemente, da releitura dos signos cristãos, a partir dos universos cosmológicos africanos. Nesse sentido, a coroação dos reis do Congo tinha amplo significado para as comunidades cativas, sendo outra forma de reconstrução de suas identidades no âmbito colonial. Esta festa era permitida em razão da ambiguidade em sua leitura: para os proprietários, era símbolo da submissão dos mancípios, mas, para estes, era forma permitida de aproveitar e viver a vida, rememorando a ancestralidade. Era, dessa forma, um espaço de afirmação de identidades que rememoravam as origens africanas nas Américas, mas que não induzia à sujeição social, posto que muitos evadiam e formavam quilombos, ou mesmo, como neste caso, organizavam revoltas. A sabedoria dos vencidos, como demonstra James Scott, está em saber levar a vida, e esperar o momento adequado para atacar. Dificilmente, diante de tamanha desvantagem, essas comunidades praticariam enfrentamentos suicidas. ${ }^{49}$

Os cativos apropriavam-se dos rituais católicos, ouviam missa, batizavam seus filhos, casavam-se nas igrejas e enterravam seus mortos no espaço sagrado, contudo, continuavam a desejar a sua liberdade. Para os mancípios que, devido aos maus tratos e outras circunstâncias optaram por evadir, as festas religiosas propiciavam excelente oportunidade. Forneciam também, por outro lado, ocasião adequada para aqueles que, por diversas razões, desejavam retornar a seus senhores, mas, temendo os castigos que receberiam, buscavam formas de proteção. Figuras de grande respeito no mundo colonial, os padres ou proprietários "bondosos" poderiam interceder pelos fujões que retornavam da petit marronage. Re-encaminhados a seus 
50

Essas pequenas fugas ou petit marronage eram comuns no período escravista, verificadas no Sul dos Estados Unidos, Caribe, América hispânica e portuguesa; e a intercessão paternalista de senhores bons, de padres ou figuras de maior respeito na época era vista com distinção pelos outros senhores. PRICE, Richard (ed). Op. Cit. p.118; FICK, Carolyn E. Op. Cit., p.6.

51

Como relatou João José Reis, enquanto o conde da Ponte mantinha uma política de sistemática repressão às manifestações em que os africanos se associavam, o conde de Arcos interpretava esses eventos de outra forma, como sossego nas senzalas, pois as festas permitiam a liberação de energias que, contidas, poderiam explodir em rebeliões, por isso, concedia alguma liberdade para os mesmos se reunirem aos domingos e dias santos. REIS, João José; SILVA, Eduardo. Op. Cit., p.38-39.

52

PEREIRA, Nuno Marques. Op. Cit., p.123-124.

53

SC, cod.11, fl.188v. Bando do governador D. Pedro de Almeida. Vila do Carmo, 20 de maio de 1720. A "côngrua régia" era a "Remuneração anual paga pela Coroa ao clero secular com cargos colados (confirmados), para seu sustento, em virtude do regime de padroado, pelo qual a Coroa recolhia em seu favor os dízimos eclesiásticos e, em troca, arcava com as despesas com os sacerdotes e o culto divino". CÓDICE COSTA MATOSO. Coleção das notícias dos primeiros descobrimentos das minas na América que fez o doutor Caetano da Costa Matoso sendo ouvidor-geral do Ouro Preto, de que tomou posse em fevereiro de $1749, \&$ vários papéis. Vol.02. Belo Horizonte: Fundação João Pinheiro, Centro de Estudos Históricos e Culturais, 1999. p.87. proprietários depois de alguns conselhos, e sob a proteção de seus "padrinhos", os escravos tinham a promessa de terem o castigo aliviado. ${ }^{50}$

Mas nem todos viam as festas negras e as práticas religiosas africanas com tranquilidade: as posições variavam entre as autoridades, como os governadores condes da Ponte e de Arcos, da Bahia oitocentista, que mantinham posturas opostas em relação à permissão da manutenção de práticas culturais africanas. ${ }^{51} \mathrm{Ou}$ ainda, como relatou Nuno Marques Pereira, no diálogo entre o "Peregrino da América", personagem central da obra, e um senhor de escravos que o acolheu. Pela manhã, ao arguir o seu convidado se havia passado bem à noite, o peregrino respondeu que, apesar das acomodações serem muito satisfatórias, ele não fechara os olhos, assombrado com o "horrendo alarido" produzido pelos cativos, que cantavam e tocavam atabaques, pandeiros, ganzás, botijas e castanhetas à noite, o que representou como a "confusão do inferno", fato que estranhou o proprietário de escravos, pois estava tão acostumado a tais festejos que isso o tranquilizava. ${ }^{52}$

Além das interpretações pessoais das autoridades coloniais, a percepção das manifestações culturais dos escravos também dependia do contexto específico. Após ser sobressaltado com a tentativa de sublevação escrava, em 1719, é compreensivel que D. Pedro de Almeida se acautelasse. Nesse caso, ele tomou diversas decisões: proibiu as alforrias - prática comum no altiplano mineiro setecentista -, tentou impedir que os escravos escolhessem outros negros para padrinhos, ordenou que os negros e mulatos, escravos ou forros, que possuíssem cativos os vendessem para evitar as dependências entre si e vetou ainda a coroação dos reis do Congo nas festas do Rosário do Serro, festa que já havia sido realizada diversas vezes nessa região, o que indica que, antes, elas não eram percebidas como "perigosas à República". Como afirmou Assumar, um dos principais cuidados de seu governo era desarmar os escravos e "tirar-lhes aquelas forças que inconsideradamente lhes permitiam seus senhores por ser esta licença ocasião de vários excessos e desaforos [sic]". Por isso "faltava remediar" na região do Serro do Frio "que nas suas festas aclamem e coroem os negros Reis e Rainhas", ato e solenidade considerados repugnantes com a sua condição servil, isso para "fazê-los conhecer a sujeição" e ainda para que "nem pela memória lhes passe este estímulo e incentivo de maioria e superioridade [sic]". Dessa forma, o governador impediu essa celebração, pois do contrário, "sendo o negro cativo o perderá seu Senhor [sic]", e seu valor seria dividido, metade para a fazenda Real e a outra, para o denunciante, mas "sendo forro, será açoitado ao pé do pelourinho e degredado". Além disso, o vigário que empossar o rei negro perderia a côngrua régia. ${ }^{53}$

Esse documento, ainda inédito, e que ressalta aspectos importantes sobre a organização das comunidades escravas nas Minas, resultou de várias medidas tomadas por D. Pedro de Almeida para o "sossego" público. Esta não foi uma iniciativa isolada, e se justificou pela estreita semelhança entre essa cerimônia, que tinha caráter religioso, e a coroação de reis, rainhas, príncipes, e demais "cabeças" da tentativa malograda de sublevação negra, tornando-se um indicador da relação de subordinação entre os cativos na festa. Reitera-se também que, nesse caso, os líderes da revolta não eram africanos recém-chegados do tráfico, mas sim escravos "ladinos", pertencentes a "homens bons", muitos dos quais agentes da administração colonial, e contavam com a confiança de seus proprietários. Outros 
54

Concorda-se aqui com Marina de Mello e Souza, quando afirmou que: "Com o estilhaçamento das relações familiares provocado pelo tráfico, os africanos escravizados buscaram reconstruir em novas bases os laços fundamentais que uniam as pessoas, sendo a ligação entre malungos, como jà vimos, a primeira alternativa encontrada, ainda durante a travessia do Atlântico. A reunião em grupos oriundos da mesma etnia ou de regiões próximas, pertencentes a um mesmo complexo sócio-cultural, foi outra forma encontrada para recriar as afinidades antes fundadas nas relações de parentesco". Op. Cit., p.181-182.

55

SC, cod.07, fl.98. Ordem. Antônio de Albuquerque Coelho de Carvalho, Ribeirão do Carmo, 09 de maio de 1711.

56

SC, cod.13, p.20. Carta aos oficiais da câmara de Vila Rica, 08 de fevereiro de 1721.

57

SC, cod.13, p.20. Carta aos oficiais da câmara de Vila Rica, 08 de fevereiro de 1721

58

SC, cod.37, fl.59-59v. Portaria proibindo o ajuntamento de negros. Vila Rica, 03 de agosto de 1734 [grifo meu]. "cabeças" não eram sequer cativos, e sim forros que mantinham relações de sociabilidade e solidariedade com mancípios de sua "nação". Mais do que uma simples festa de gentes de cor, a coroação de reis negros nas Minas tornava-se uma forma de união identitária dos escravos, que certamente extrapolava os momentos festivos ${ }_{1}^{54}$ o que era temido por Assumar.

\section{Apontamentos finais: as festas negras nos dias santos}

A sublevação escrava, organizada para ocorrer na quinta-feira das endoenças de 1719, isto é, em plena semana santa, causou grande repercussão e gerou a produção de considerável volume de documentos, influenciando as medidas de prevenção tomadas pelas autoridades posteriores. Antes mesmo de 1719, como denunciou Assumar, já haviam ocorrido tentativas de rebeliões escravas nesta capitania. Em 1711, houve um levantamento dos negros minas na região do Ribeirão abaixo, ocasião em que os negros desta "nação" se agruparam para matar os brancos. Como em 1719, os "cabeças" dessa revolta pertenciam a homens ilustres da capitania, como o capitão Antônio Furquim da Luz, o superintendente Joseph Rebello Perdigão e 0 padre Phelipe de la Contria - clérigo francês que vivia nessas paragens. Enquanto reuniam os membros de sua "nação", o motim foi denunciado pelos escravos de Pedro Monteiro de Mattos, que também foram convidados a participar. ${ }^{55}$

Em carta de fevereiro de 1721, D. Lourenço de Almeida acusou o recebimento de uma mensagem enviada pelos oficiais da câmara de Vila Rica, onde informaram:

as queixas que havia já dos moradores da rua da paz e dos tumultos dos negros que ali se ajuntava, particularmente aos dias santos e que os vendilhões se opunham aos senhores que iam buscar os seus [sic]. ${ }^{56}$

Para dar fim ao tumulto, este governador determinou que estes "ranchos" deveriam mudar de local, além disso, ordenou que se fizesse uma ronda com "os mesmos moradores da Rua da Paz", além de dois sargentos "e seis ou oito homens armados com ordem que embaracem que estejam muitos negros juntos e lhe tomem as armas com que andarem e os prendam [sic]", para que fossem castigados conforme o seu bando. Acreditou-se que não seria necessário demolir as ditas vendas, ou ranchos, uma vez que "maior perigo há que os negros se juntem em grande número no morro do que na Vila, aonde os brancos veem e podem acudir com mais prontidão a qualquer insulto". Observe que, ironicamente, a confusão ocorreu na Rua da paz. ${ }^{57}$

Treze anos mais tarde, em 1734, muitos escravos vagavam no morro da Passagem, caminho de Vila Rica para a Vila do Carmo, no Arraial de baixo e nas estradas que conduziam ao Ribeirão do Carmo, munidos de "bastões grossos, porretes e paus compridos e outras armas principalmente nos Domingos e dias santos". Desacato temivel, uma vez que, segundo o relato, os seus senhores não podiam contê-los, "nem impedir as desordens que cometem desobedecendo-Ihes [e] revoltando-se contra os mesmos brancos que procuram aquietá-los antes insultando-os não só com palavras mas com armas [sic]". Como punição aos delinquentes e cabeças das arruaças, foi dada ordem de prisão, recomendação igualmente sugerida àqueles que "fizerem reuniões com batuque e bebedices à noite $[$ sic]".58 
59

SC, cod.27, fl.23-23v. Bando de D. Lourenço de Almeida, governador das Minas. Vila Rica, 14 de abril de 1726 [grifo meu].

60

Câmara Municipal de Ouro Preto (CMOP), cod.06, fl.94v. Bando de D. Lourenço de Almeida, proibindo 0 uso de bordões e armas aos negros e cativos. Vila Rica, 31 de março de 1730 [grifo meu].

61

SC, cod.37, fl.24v/25. Bando de André de Melo. Vila Rica, 26/?/1733.

SC, cod.4, fl.218-219v. Carta do conde de Assumar ao rei. Vila do Carmo, 20 de abril de 1719.

Recebido para publicação em outubro de 2010 Aprovado em abril de 2011
Nos anos de 1726 e 1730, novos bandos foram publicados na tentativa de coibir o porte de armas e a violência causada pelos escravos e gentes de cor, principalmente na Semana Santa. No primeiro caso, D. Lourenço de Almeida proibiu a utilização de armas a todas as castas "no arraial de Guarapiranga durante esta Semana Santa, Dia da Páscoa e Suas oitavas". 0 motivo da repetição dessa ordem é que "neste tempo da Semana Santa e dias de páscoa costumam os negros com ocasião das ocupações espirituais de seus senhores (...) e por se verem mais livres da sujeição" cometem insultos e "perturbações muito contrárias ao comum sossego [sic]". Além disso, esses causam prejuízos a seus proprietários. ${ }^{59} 0$ bando publicado em 1730 segue o mesmo padrão do anterior. Os escravos perambulavam por Vila Rica com bordões, matando e ferindo-se uns aos outros, causando prejuizos aos senhores e atemorizando os transeuntes e moradores, "principalmente na Semana Santa, em que se ajuntam a maior parte dos negros". Para evitar essas desordens, novamente proibiu-se o uso de bordões "de nenhuma casta" ou qualquer tipo de arma, pois, do contrário, se o infrator não estiver com seu proprietário, "será logo preso e metido na cadeia e o juiz ordinário the mandará logo dar no pelourinho duzentos açoites", continuando preso na cadeia pelo tempo que o governador estabelecer [sic]. ${ }^{60}$

A contínua repetição das proibições do uso das armas por parte dos negros e mestiços demonstra que estas leis não eram cumpridas, e que as desordens na semana santa eram comuns, ainda mais porque nestas ocasiões muitos proprietários se dirigiam às vilas com escravos armados. Para evitar semelhantes desordens, em 1733, foi ordenado o desarmamento dos cativos que pertenciam àqueles senhores que vinham de fora da vila, $\mathrm{e}$ também dos pretos dos moradores que assistiam na mesma, isso sob pena de terem seus escravos presos e multados em cinquenta oitavas de ouro. ${ }^{61}$ Esse fato tratava-se de uma velha prática escravista: o uso contínuo de pretos armados que serviam como seguranças pessoais de seus senhores, principalmente quando estes estavam em trânsito. 0 risco em potencial era que, no momento da festa, os cativos acabassem se desviando e causassem violência a terceiros.

Nas épocas festivas, quando o ajuntamento da população era maior aumentando mais ainda a desvantagem do número de negros em relação aos brancos - os africanos e descendentes tornavam-se, de fato, uma ameaça potencial. Assim, ao invés de submeter os escravos, a religião tornou-se espaço para melhor viver, e as festas litúrgicas o lugar propício para brincar e folgar, mas também para se revoltar. A escolha das festas religiosas para as sublevações escravas exemplifica bem a astúcia negra. Os escravos não se arriscavam à toa, era preciso haver condições favoráveis à revolta.

Por fim, observa-se que os escravos participavam da religião, mas aguardavam também o momento de se libertarem. Como tão bem mostrou Eugene Genovese, a "terra prometida" para os africanos não estaria somente no céu, e a travessia do rio Jordão - que na Bíblia simboliza a passagem do povo judeu da escravidão do Egito para a liberdade - pode também significar, para os escravos, a busca da libertação neste mundo. Nas Minas, em diversas ocasiões, os escravos esperavam conquistá-la, através das alforrias, mas também formando comunidades quilombolas, ou pela força das armas, nas sublevações. 0 próprio conde de Assumar, de forma inconsolável, chegou à conclusão de que, apesar de todos os esforços usados na repressão, e esse governador sabia como ninguém aplicá-las, "aos [escravos] que ficam se thes não podem tirar os pensamentos e os desejos naturais de liberdade [sic]"62 